\title{
POETRY AND EMPHATIC TRUTH: WALTER BENJAMIN's READING OF HÖLDERLIN ${ }^{1}$
}

\author{
POESÍA Y VERDAD ENFÁTICA: \\ LA LECTURA DE HÖLDERLIN POR BENJAMIN
}

Richard Eldridge

\begin{abstract}
RESUMEN
El presente trabajo comenta la teoría poética de Walter Benjamin. Se hace notar que Benjamin sigue a Hölderlin al considerar que un verdadero poema es una configuración particular en la que se juntan los órdenes intelectual y perceptivo. Un verdadero poema aspiraría no a la verdad como correspondencia con un objeto determinado, sino a algo que en el texto se describe como "verdad enfática".
\end{abstract}

PALABRAS CLAVE: Walter Benjamin, Hölderlin, verdad enfática, crítica literaria

\begin{abstract}
Benjamin's poetic theory is commented. It is noted that Benjamin follows Hölderlin in regarding a successful poem as a particular configuration that joins the intellectual and perceptual orders. Such a successful poem aims at and can possess not truth as correspondence to a given object, but rather what in the text is described as "emphatic truth".
\end{abstract}

KEYWORDS: Walter Benjamin, Hölderlin, emphatic truth, literary criticism

In a letter to Martin Buber in July, 1916, Benjamin criticizes a view of the "relationship between language and action in which the former [is merely] an instrument of the latter," and he proposes instead to understand "writing [Schrifttum] as such as poetic, prophetic, objective in terms of its effect, but in

\footnotetext{
${ }^{1}$ This text is a section from my book Images of History: Kant, Benjamin, Freedom, and the Human Subject, forthcoming (Fall 2016) from Oxford University Press.
} 
any case only as magical [magisch], that is as un-mediated [un-mittel-bar]."' As both the context of a letter to Buber (against a background of discussions of Kabbalah with Scholem) and the word "Schrifttum," which describes professional, learned, or sacred texts, in contrast with the more colloquial "Schreiben" for writings in general, suggest, Benjamin is here concerned with a particular and specialized kind of writing, not with all written texts, in particular with a kind of writing that can be prophetically effective for action in relation to fundamental issues of life. Somewhat paradoxically, this specialized form of writing wins its effectiveness through "the crystal-pure elimination of the ineffable [die kristallreine Elimination des Unsagbaren]": "only where this sphere of speechlessness [diese Sphäre des Wortlosen] reveals itself in unutterably pure power can the magic spark leap between the word and the active deed [bewegender Tat], where the unity of these two is immediately actual."'3 Benjamin's modernist distaste for instrumentalist planning and for decoration, ornamentation, and personal expression plus his contrasting preference for exactness of description are already here fully developed and on display. As Philippe Lacoue-Labarthe remarks about this letter, "this page contains the poetic art of Benjamin, [and] he remained faithful to it in all he wrote."4

As well as being broadly derived from a concept of the sacred object, the general idea of a work of literary art as effective through the achievement of presence is prominent in the German tradition at least as far back as Lessing's 1766 essay Laocoön, where, while in the first instance sharply differentiating the effects and techniques that are proper to the distinctive media of painting and poetry, Lessing also goes on to pose as a normative demand for poetry the achievement of the "painterly [malerisch]," a "combination of features by means of which the poet makes his subject so perceptible that we are more clearly conscious of this subject than of his words." 5 The achievement of such presence in the work affords the reader an experience of absorption in the work as it presents its subject. The presentation of the subject in the work is hence anschaulich or intuitive in guiding the reader's attention to just this thing, presented in just this way there, not primarily discursive or classificatory. The painterliness that the successful poem achieves in its sensuous presence to the reader falls under the heading of Anschaulichkeit: an imagistic clarity or understandability, where one engages with

\footnotetext{
${ }^{2}$ Benjamin (2012, p. 80); GS Briefe I, p. 126.

${ }^{3}$ Ibid., p. 80; GS Briefe I, p. 127 (translation modified.)

${ }^{4}$ Lacoue-Labarthe (2002, p. 12).

${ }^{5}$ Lessing (2003, p. 79).
} 
both the work and its presented subject matter by way of the focus of perception on a this. At the same time, however, just in virtue of requiring and affording a temporally extended experience of reading, the literary work that achieves this kind of Anschaulichkeit also requires intellectual and discursive activity on the part of the reader, who further has available the possibility of reflection throughout the experience of reading.

Describing this achievement and characterizing its importance philosophically is a major topic of Hölderlin's poetic theorizing, where he emphasizes the importance of harmonious alternation in the experience of the successful poem between free reflection and absorption in sensuous presentation. "The foundation and significance of the poem... lies between the expression (presentation) and the free idealistic treatment.... This is what lends the poems its seriousness, its firmness, its truth; it protects the poem [by assuring] that the free idealistic treatment [--the thematization that is taken up in the reader's reflections--] become not an empty affectation, and the presentation [of the particular subject in just this way] become not vanity." ${ }^{\prime \prime}$ Both potentially empty, free, idealistic moralizing, untethered to sensuous experience of an existing object and potentially vain, gratuitous, wallowing in the object or in the words that sensuously present it, without reflective thought, are to be avoided. The point of constructing a poem that embodies Anschaulichkeit in living alternation with thematic materials for reflection is to find oneself, either as reader or writer, at home in one's world, at least for a moment, as both an active and a natural, embodied being. Or, in Hölderlin's formulation, the successful poem answers to the need of the I-the human subject as such- "to recognize its unity [as a reflective, active subject] in the harmoniously opposed [--the object of configured attention--] and [to recognize] the subjective (harmoniously opposed) in its unity [as an object formed for its attentions]." An experienced object that supports a successfully modulated poem as a form of attention to it thus functions, in Thomas Pfau's useful phrase, as a vehicle of "analeptic Ahndung" or restorative presentiment. ${ }^{8}$

\footnotetext{
${ }^{6}$ Hölderlin (1988, p. 66).

${ }^{7}$ Ibid., p. 75.

8 Pfau (1988, p. 28). "Ahndung" is Hölderlin's archaic, Swabian spelling of "Ahnung"; "analeptic" is a medical term meaning "restorative" or "stimulative." The object that is experienced in and through the poem is more than either a thing simply recognized under a concept or a source of immediate sense experience. Instead it is an an object that is both received and attended to, in such a way that the experiencing subject feels more fully its powers as a subject as potentially effective in relation to empirical life.
} 
Following Hölderlin, Benjamin develops his own poetic theory in his 191415 "Two Poems by Friedrich Hölderlin." Like Hölderlin, Benjamin regards the successful poem as a "particular configuration [besondere Gestalt] that joins "the intellectual and perceptual orders." Given the assumption, as Benjamin puts it in his 1919 "Fate and Character," that "between the active man and the external world, all is interaction [Wechselwirkung]; their spheres of action interpenetrate,"10 a successful poem, as a depiction not of empirical objects as such, but of human experience and of human being in relation to empirical objects, must join the intellectual and perceptual orders, in presenting a process of interaction that involves both perceptual intake and intellectual reflection. Unlike the depiction of empirical objects in relation to each other and apart from human involvement, so far as this is possible and achieved in either natural science or mere recognitive perception, for Benjamin, "the act of poetizing" has, in Fenves' formulation, "an objective intention [that] is categorically different from any other act, .... [where] the 'truth' of poetry is not understood as the correspondence between thinking and being or between subject and object but, rather, in terms of 'fulfillment' (Erfüllung), on the one hand, and 'objectivity' (Gegenständlichkeit), on the other."11 The successful poem must present, in Hölderlinian terms, a modulated sequence or alternation of thoughts and perceptions that are bound together in attending to an object. ${ }^{12}$

This distinctive objective intention or aim to be realized in successful poetizing is not limited only to lyric poetry. It covers other forms of modern literary art, such as drama and the novel. Given that literary reading itself involves active, modulated, perceptual, and reflective attention to a work, seeking orientation in relation to the experience of it, just as orientation is sought within the literary work in its attention to its object, this distinctive objective intention covers the aim of criticism, too. ${ }^{13}$ As Winfried Menninghaus puts it, explicating and citing Benjamin's doctoral dissertation on German Romanticism,

\footnotetext{
${ }^{9}$ Benjamin (2002, p. 19); GS II, 1, p. 106.

${ }^{10}$ Benjamin (2002a, p. 202); GS II, 1, p. 173.

${ }^{11}$ Fenves (2010, p. 23).

${ }^{12}$ See Hölderlin's thought that "poetic life with respect to its content remains ...essentially unified ... [insofar as] it exists as such in definite form and progresses through the alternation of moods where each time the succeeding mood is determined by the preceding one" (1988, p. 68).

13 Though it is present already in Benjamin's Hölderlin essay, this idea is not directly derived from Hölderlin, for whom poetry was sharply distinct from both criticism and philosophy. The
} 
As a representation of works based on their own features, critique is not a judgmental 'reflecting on a work of art', but rather a consciousness-raising 'unfolding', in a new formation, of that 'reflection' which itself already exists in the work as its structural principle. Both work and critique are thefore 'relative' moments in the same medium of reflection. ${ }^{14}$

Within both poetry and criticism, the fulfillment and objectivity (Erfüllung and Gegenständlichkeit) that are sought involve a fullness in both presenting and embodying a modulated but incomplete experience that fails, necessarily, fully to capture a given, discrete object for a given, discrete subject. In presenting a modulated but open alternation of perceptions and reflections, the successful poetical and critical work embodies what Benjamin came in his Goethe essay to call a Wabrheitsgehalt or truth-content, distinct from its Sachgehalt or material content-its subject matter (theme plus plot) plus arrangement of words. ${ }^{15}$ While embodied in the Sachgebalt and only analytically distinct from it- "the more significant the work, the more inconspicuously and intimately its truth content is bound up with its material content,"16 a successful work's Wabrheitsgehalt is its embodiment and presentation of the vicissitudes of an aptly attentive subject to the Sachgehalt throughout the subject's alternations of mood, perception, and thought, vicissitudes marked in the successful work by both a fullness of modulated attention and a constitutive incompleteness arising out of an insuperable gap between the discursive human subject and the course of nature as a whole. Hence, as Beatrice Hanssen puts it, the achievement of Wabrheitsgehalt, in presenting these vicissitudes, runs

counter to the poetical ideal of ever attaining a revealed language of plenitude. ...It [offers] a philosophical anamnesis of nature, a figure suppressed in Hegel's philosophy of spirit, .... radically different mode of recollection [from that of Plato or Hegel] consist[ing] of a reflection to the second power in which reflection pondered its own negativity and finitude. ${ }^{17}$

idea that criticism and philosophy should themselves be poetically organized is prominent, however, in the fragments of Friedrich Schlegel, and it is developed by Benjamin at length in his doctoral dissertation "The Concept of Criticism in German Romanticism."

${ }^{14}$ Menninghaus (2002, p. 49), citing Benjamin's "The Concept of Criticism in German Romanticism," SW I, pp. $151 \mathrm{ff}$ and SW I, p. 146.

${ }^{15}$ See Benjamin (2002b, p. 297); GS 1, 125.

${ }^{16}$ Ibid.

${ }^{17}$ Hanssen (2002, pp. 141-42). 
The direct argument of the 1914-15 essay on Hölderlin turns on close comparisons between Hölderlin's second draft of a lyric that describes the stance of the poet, "The Poet's Courage [Dichtermut]", 1801, and his immediate revision of it, "Timidity [Blödigkeit]", also 1801. These comparisons emphasize the relatively dogmatic, assertational character of the earlier version, contrasted with the more open, processual, experience-related, living, and modulating character of the later version. Thus Benjamin remarks that the earlier version foregrounds "mythology" over "perceptual world formation," as though the thought of the poem were formed first, via reading and general reflections alone, independently of perceptual experience. Hence Hölderlin in the earlier version is caught up in "grasping at externals," and "the indeterminacy of the shaping figure ... dissolves the figure of the poet," insofar as we are unable or less able to recognize in the development any modulated alternations on the part of a plausibly living speaker. The Parcae or Fates who are invoked are "related [verwandt]" as it were observationally, or introduced as symbols, rather than being in any way present in experience. The poet simply "reaches with both hands into an alien world order, grabs at people and God to raise within him his own courage." The result is an isolated, static image manifesting "a nonperceptual conception of life, an unmythic, destiny-less concept of life stemming from a spiritually exiguous sphere." In the later version, in contrast, "the gods and the living are bound together," in alike living within fateful life processes, without orienting certainties. The Parcae are "recognized [bekannt]" as similar to the poet and the people, rather than invoked or presented as symbolic spiritual others. "At the center of the poem men, heavenly ones, and princes - crashing down from their old orders, as it were, are linked to one another." "A structuring movement" of modulation in thoughts, perceptions, and reflections on the part of an attentive, nondogmatic, and recognizably living subject runs "from verse to verse." "The traditional and simple superiority of mythology is transcended" in favor of genuineness of presentation of the poet bound within the destiny of a "situation" [Lage] wherein attention and reflection are possible, even skillfully achievable, but never completable. ${ }^{18}$

These comparisons are developed on the basis of an initial general poetic theory that centers on the concept of das Gedichtete, the poetized. Benjamin defines this, initially somewhat paradoxically, as "the particular and unique sphere in which the task and precondition [Aufgabe and Voraussetzung] of the poem

\footnotetext{
${ }^{18}$ All quotations in this paragraph are from Benjamin (2002, pp. 23-27); GS II, pp. 109-14.
} 
lie." 19 The air of paradox diminishes somewhat if "of the poem" is emphasized in this sentence. That is to say, for any particular poem, there is a distinctive situation of a worldly subject undergoing a course of experience that is to-be-addressed or worked through. ${ }^{20}$ That there is such some such situation is, as Benjamin says, a precondition for any particular poem, and the poem, in turn, has the task of working it through. Hence it is true both that "the task is derived from the poem itself" - - that is, from the situation to be addressed on which it distinctively focuses, and "the task"---that it is to work through this- "is also to be understood as the precondition of the poem." ${ }^{21}$ Benjamin describes the situation of a subject in the world that is to-be-worked through as "the intellectual-perceptual [geistiganschaulich] structure of the world to which the poem bears witness [die geistiganschauliche Struktur derjenigen Welt, von der das Gedicht zeugt]." ${ }^{22}$ Here the term "world" [Welt]" indicates, as in Heidegger's contrast between world [Welt] and earth [Erde], not either nature or the material stuff of the universe as a whole, but rather a course of experience within a situation. Something has happened to or for an experiencing subject, over some period of time, within a situation, and this something that has happened-the intellectual-perceptual content of this situated experience, an initially perplexing course of perceptions, reflections, emotions, and attitudes - is to be addressed, worked through, and brought to clarity. It is the situation of the subject in the world or the full content of the subject's experience that the poem takes as both its subject matter (precondition) and its material to be worked through (task).

Hence the "'truth' [of the poem], which the most serious artists so insistently claim for their creations, shall be understood as the objectivity [Gegenständlichkeit] of their production, as the fulfillment [Erfüllung] of the artistic task in each case. ${ }^{23}$ The poem, that is, achieves its truthfulness or fulfillment when it embodies fullness of attention to its [geistig-anschaulich] experienced object, without lapsing into shirking, reverie, or cliché. Perceptual content, thought, and emotional stance within a worldly situation are modulated. There is developing content that is presented over the course of time of the poem, and this presentation of developing content within the poem attends to, works though, and intensifies, in

\footnotetext{
${ }^{19}$ Ibid., p. 18; GS II, p. 105. pp. 111-12, 119).

${ }^{21}$ Benjamin (2002, p. 18); GS II, p. 105.

${ }^{22}$ Ibid.

${ }^{23}$ Ibid., p. 19; GS II, p. 106.
}

${ }^{20}$ Compare the discussion of working through as the task of literary art in Eldridge (2008, 
being free from distractions and irrelevancies, the course of experience within a worldly situation that was to be worked through. The poem achieves, that is to say, a "synthetic unity of the intellectual and perceptual orders," 24 in that the course of thoughts, the course of perceptions, and the course of emotional stances are apt to one another. There is an achievement of fullness of attention on the part of an experiencing subject, embodied in "the fundamental aesthetic unity of form and content," ${ }^{25}$ where "aesthetic unity" indicates an appropriate modulated and developed relation among elements that remain distinct from one another as moments of the experience.

This amounts, in turn, to the achievement of fuller life as an attentive subject. "For the creator, the idea of the task is always life. ...In [the poetized] life determines itself through the poem, the task through the solution [bestimmt sich das Leben durch das Gedicht, die Aufgabe durch die Lösung]."26 That is, the life of the subject takes on more intensity, a shape of fuller attentiveness, through the composition of the poem, and that very solution in turn characterizes and reveals the problem situation that was to be worked through. "(For task and solution can be separated only in the abstract.) [(Denn Aufgabe und Lösung sind nur in abstracto trennbar,)]"27 Insofar as a successful poem-one that avoids shirking, reverie, and cliché-achieves an "intensity of the coherence of the perceptual and intellectual elements" as opposed to "a slack extension of feeling" [eine schlaffe Ausdehnung des Gefuhls], "a judgment, even if unprovable [zu beweisen], can be justified [zu begrunden]," ${ }^{, 29}$ insofar as a critic may similarly work through in an attentive modulated way the experience of the diverse elements of the poem. ${ }^{30}$ This kind of criticism itself poetically unfolds the composed content of the poem in the interest of fullness of attention to $i$. Both the poem and criticism as unfolding commentary aim at and can possess not truth as correspondence to a

\footnotetext{
${ }^{24}$ Ibid.

${ }^{25}$ Ibid.

${ }^{26}$ Ibid., pp. 19-20; GS II, p. 107.

${ }^{27}$ Ibid., p. 19; GS II, p. 107

${ }^{28}$ As David Wellbery usefully notes, "Benjamin repudiates the vitalist ideology of immediate expression which animates virtually of post-Diltheyan Literaturwissenschaft," focusing instead on the work as composed expression, more in the manner of New Criticism than of any form of biographical criticism (1986, p. 27).

${ }^{29}$ Benjamin (2002, pp. 20, 21); GS II, 107, 108.

${ }^{30}$ Two important articles that develop this conception of critical working through, altogether independently of Benjamin's work, are Isenberg (1949) and Cavell (1969).
} 
given object, but rather what David Wellbery aptly describes as "emphatic truth" in the fulfillment via composition of the poem's task. ${ }^{31}$ This emphatic truth in the service of fuller life, achieved in and through the work, is the aim of literary, philosophical, and critical work as such.

\author{
Richard Eldridge \\ Swarthmore College \\ reldrid1@swarthmore.edu
}

\title{
REFERENCES
}

Benjamin, W. (2012): The Correspondence of Walter Benjamin, Chicago: University of Chicago Press; Gesammelte Schriften, unter Mitwirkung von Theodor W, Adorno und Gershom Scholem, herausgegeben von Rolf Tiedemann und Hermann Schweppenhäuser, Suhrkamp Verlag, Briefe I [GS]

— (2002): "Two Poems by Friedrich Hölderlin," in Walter Benjamin Selected Writings: 1913-

1926, vol. 1, Harvard University Press, 2002, pp. 18-36 [SW]; GS II, 1.

- (2002a): "Fate and Character", in SW I, pp. 201-206; GS II, 1

- (2002b): “Goethe's Elective Affinities," in SW I, pp. 297-360; GS 1

Cavell, S. (1969): "Aesthetic Problems of Modern Philosophy," in Cavell, S., Must We Mean What We Say?, New York: Charles Scribner's Sons, pp. 73-96.

Eldridge, R. (2008): Literature, Life, and Modernity, New York: Columbia University Press. FENveS, P. (2010): The Messianic Reduction. Walter Benjamin and the Shape of Time, Stanford: Stanford University Press.

Hanssen, B. (2002): “'Dichtermut' and 'Blödigkeit': Two Poems by Friedrich Hölderlin Interpreted by Walter Benjamin,” in BEATRICE HANSSEN and ANDREW BENJAMIN (eds.), Walter Benjamin and Romanticism, New York: Continuum, pp. 139-162.

HÖlderlin, F. (1988): "On the Operations of the Poetic Spirit," in HÖlderlin, F., Essays and Letters on Theory, ed. and trans. Thomas Pfau, Albany: State University of New York Press.

Isenberg, A. (1949): “Critical Communication,” Philosophical Review 57 (July 1949), pp. $330-44$.

LACOUE-LaBARTHE, P. (2002): "Introduction to Walter Benjamin's The Concept of Art Criticism in German Romanticism," in BEATRICE HANSSEN and ANDREW BENJAMIN (eds.), Walter Benjamin and Romanticism, New York: Continuum, pp. 9-18.

Lessing, G. W. (2003): Laocoön: An Essay on the Limits of Painting and Poetry, (trans. W. A. Steel), in J. M. Bernstein (ed.), Classical and Romantic German Aesthetics, Cambridge: Cambridge University Press.

${ }^{31}$ Wellbery (1986, p. 31). 
MEnNinghaus, W. (2002): “Walter Benjamin's Exposition of the Romantic Theory of Reflection," in BEATRICE HANSSEN and ANDREW BENJAMIN (eds.), Walter Benjamin and Romanticism, New York: Continuum, pp. 19-50.

PFAU, T. (1988): "Critical Introduction," to Hölderlin, Essays and Letters on Theory, Albany: State University of New York Press, pp. 1-29.

Wellbery, D. (1986): "Benjamin's Theory of Lyric", Studies in 20th Century Literature, 11 1 (Fall 1986), pp. 25-44. 